University of Nebraska - Lincoln

DigitalCommons@University of Nebraska - Lincoln

Publications from USDA-ARS / UNL Faculty

U.S. Department of Agriculture: Agricultural

Research Service, Lincoln, Nebraska

November 1994

\title{
Imbibition Response of Winter Wheat to Water-Filled Pore Space
}

\author{
Guillermo A. Studdert \\ Univ. Nac. de Mar del Plata, Buenos Aires, Argentina \\ Wallace Wilhelm \\ University of Nebraska-Lincoln, wwilhelm1@unl.edu \\ James F. Power \\ USDA-ARS
}

Follow this and additional works at: https://digitalcommons.unl.edu/usdaarsfacpub

Part of the Agricultural Science Commons

Studdert, Guillermo A.; Wilhelm, Wallace; and Power, James F., "Imbibition Response of Winter Wheat to Water-Filled Pore Space" (1994). Publications from USDA-ARS / UNL Faculty. 84.

https://digitalcommons.unl.edu/usdaarsfacpub/84

This Article is brought to you for free and open access by the U.S. Department of Agriculture: Agricultural Research Service, Lincoln, Nebraska at DigitalCommons@University of Nebraska - Lincoln. It has been accepted for inclusion in Publications from USDA-ARS / UNL Faculty by an authorized administrator of DigitalCommons@University of Nebraska - Lincoln. 


\title{
Imbibition Response of Winter Wheat to Water-Filled Pore Space
}

\author{
Guillermo A. Studdert, Wallace W. Wilhelm,* and James F. Power
}

\begin{abstract}
Reduced temperature and increased bulk density associated with conservation tillage systems cause lower seed germination, seedling emergence, and early growth rates resulting in reduced plant stands. Prediction of the influence of soil condition on seed imbibition through simple soil measurements would help make agronomic decisions such as planting date and/or density. Our objectives were to evaluate the influence of soil water-filled pore space on winter wheat (Triticum aestivum $\mathbf{L}$.) seed imbibition and to assess the possibility of describing the relationship through simple mathematical models. We measured the rate of water uptake by heat-killed wheat seeds at three levels of water-filled pore space (WFPS: $0.35,0.60$, and 0.85 ) and temperature ( $T: 278,283$, and $288 \mathrm{~K}$ ) and two levels of bulk density ( $\rho_{\mathrm{b}} ; 1.25$ and $1.40 \mathrm{Mg} \mathrm{m}^{-3}$ ) in a Sharpsburg silty clay loam topsoil. The model proposed in 1972 by Blacklow to estimate seed water content $\left(\theta_{\mathrm{s}}\right)$ after imbibing water for time $t, \theta_{\mathrm{s}(t)}=(m+o t)-\left(m-\theta_{\mathrm{s}(0)}\right) \mathrm{e}^{-q t}$, was fitted to seed water content as a function of time and initial seed water content, $\theta_{\mathrm{s}(0)}$. This equation adequately described the process of water absorption (for 18 treatment combinations, $R^{2} \geq 0.963$ ). The model parameter $o$ was related $\left(R^{2}=0.88\right)$ to WFPS and $\rho_{\mathrm{b}}$, and $q$ was related $\left(R^{2}=0.78\right)$ to $T$ and WFPS. The third parameter, $m$, was significantly but weakly related $\left(P<0.01, r^{2}=0.26\right)$ to initial seed weight. We showed that easily measured soil properties and simple mathematical models can be used to predict wheat seed imbibition under a variety of soil conditions.
\end{abstract}

$\mathrm{P}^{\mathrm{n}}$ ROPER GERMINATION of planted seeds and establishment of seedlings are of general importance in agriculture because they determine density of stand, influence the degree of weed infestation, and in extreme situations limit yield (Hunter and Erickson, 1952; Hillel, 1972). The first phase of germination, imbibition, is characterized by rapid hydration of seed constituents and is associated with important changes in macro- and microstructure of the seed (Bewley and Black, 1978; Hegarty, 1978; Simon, 1984). Imbibition is a physical process (not associated with seed viability) that is related to seed and substrate colloid properties (Mayer and Poljakoff-Mayber, 1982).

The seed-soil system is complex, with two media (soil and seed) through which water must move. Water must also traverse the seed-soil interface during imbibition (Bewley and Black, 1978). The process of imbibition is determined by three factors: composition (chemical and structural) of the seed, characteristics of the tissues covering the seed, and availability of water in liquid or gaseous phase (Mayer and Poljakoff-Mayber, 1982). Thus, the rate at which water is taken up by seeds is a complicated function of both the soil microenvironment and intrinsic properties of the seed (Vertucci, 1989).

The driving force of water flow from the soil to the seed is the difference in water potential between the two (Bew-

G.A. Studdert, Facultad de Ciencias Agrarias, Univ. Nac. de Mar del Plata, C.C. 276, (7620) Balcarce, Buenos Aires, Argentina; and W.W. Wilhelm and J.F. Power, USDA-ARS, Dep. of Agronomy, Univ. of Nebraska-Lincoln, Lincoln, NE 68583-0938. This paper is a joint contribution of USDA-ARS and Nebraska Agric. Res. Div. and is published as Journal Series no. 10214. Received 14 Dec. 1992. *Corresponding author (Email: wwilhelm@unl.edu).

Published in Agron. J. 86:995-1000 (1994). ley and Black, 1978; Vertucci, 1989); however, soil hydraulic conductivity and seed-soil contact (Hadas and Russo, 1974; Shaykewich and Williams, 197la,b; Ward and Shaykewich, 1972) also influence imbibition. Scientists have repeatedly reported that a reduction in water potential of the surrounding medium (Hadas and Russo, 1974; Hadas, 1976, 1977; Singh and Singh, 1982), hydraulic conductivity, or seed-medium contact (Hadas and Russo, 1974; Shaykewich and Williams, 1971a; Ward and Shaykewich, 1972; Williams and Shaykewich, 1971) decreases seed water uptake rate.

Soil temperature is a factor of primary importance in determining the rates and directions of soil physical processes (Hillel, 1980b). In most seed types, the main effect of temperature is on the rate of water diffusion and uptake (Blacklow, 1972; Leopold, 1980; Vertucci and Leopold, 1983), manifest through changes in both water viscosity (Murphy and Noland, 1982; Vertucci and Leopold, 1983) and hydration pattern of cellular constituents (Crowe et al., 1989).

All soil characteristics affecting soil matric potential, hydraulic conductivity, and temperature are affected, either directly or indirectly, by soil management practices (Hillel, 1980a), especially tillage system (Unger and McCalla, 1980; Griffith et al., 1986; Mielke et al., 1986). Prediction of tillage system effects on the process of seed imbibition would be an important tool to help make agronomic management decisions (planting date and/or density). Very complex models are required to account for all the factors involved in the process (Bruckler, 1983; Bouaziz and Bruckler, 1989) and are of doubtful usefulness for general field application if based on inputs that are difficult to measure. Such a tool becomes helpful only when accurate prediction can be made based on simple measurements.

Water-filled pore space (also known as degree of saturation; Hillel, 1980b) is an easily measured soil parameter; it is the volume of water present in the soil relative to total volume of pores. Past research has demonstrated that soil WFPS adequately explained the variation in soil microbial activity under different tillage systems (Linn and Doran, 1984; Doran et al., 1988). We proposed that a close relation also exists between seed imbibition and the combined effect of soil WFPS, temperature, and bulk density and that quantification of this effect can be used to predict seed imbibition under various soil conditions. Therefore, we designed an experiment to determine and evaluate the influence of the combined effects of WFPS, temperature, and bulk density on wheat seed imbibition and to assess the possibility of describing these relationships through simple mathematical models.

Abbreviations and variables: $f(t)$, the linear portion of the Blacklow (1972) equation, $m+o t ; m, o, q$, curve-fitting parameters; $o_{\mathrm{c}}$, estimated value of $o$; PVC, polyvinyl chloride; $q_{\mathrm{e}}$, estimated value of $q ; t$, time; $t_{i}$, time to occurrence of event $i$ (completion of exponential phase); $T$, temperature; WFPS, water-filled pore space; $\theta_{s}$, seed water content; $\theta_{\mathrm{s}(0)}$, initial seed water content; $\theta_{\mathrm{s}(\mathrm{i})}$, seed water content at time of event $i$ (completion of exponential phase); $\theta_{\mathrm{s}(t)}$, seed water content at time $t ; \rho_{\mathrm{b}}$, bulk density; $\psi_{\mathrm{s}}$, seed water potential. 
Table 1. Particle size analysis and organic carbon content for the Sharpsburg soil used in the experiment. The site of collection was Alvo, NE $\left(40^{\circ} 51^{\prime} \mathrm{N}, 9^{\circ} 36^{\prime} \mathrm{W}\right)$.

\begin{tabular}{|c|c|c|c|c|c|}
\hline \multicolumn{3}{|c|}{ Particle size analysis, $\mu \mathrm{m}$} & \multirow[b]{2}{*}{ Organic C } & \multirow[b]{2}{*}{ Depth } & \multirow[b]{2}{*}{ Horizon } \\
\hline$<2$ & $2-50$ & $50-200$ & & & \\
\hline & 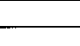 & $\xi^{-1}$ & & $\mathrm{~cm}$ & \\
\hline 0.339 & 0.631 & 0.030 & 0.017 & 0-30 & A \\
\hline
\end{tabular}

\section{MATERIALS AND METHODS}

Particle size distribution and organic $\mathrm{C}$ content of the topsoil (Sharpsburg series; fine, montmorillonitic, mesic Typic Argiudoll) used for this experiment are shown in Table 1. A soil conditioning step was performed before starting the experiment to stimulate microbial activity and improve aggregation. This step consisted of planting oat (Avena sativa L. cv. Ogle) seeds into soil at a high density $\left(\approx 1400\right.$ seeds $\mathrm{m}^{-2}$ soil $)$. Oat plants were grown in a greenhouse until the reproductive stage, when plants were cut and removed.

Three treatment factors were considered in this experiment: soil temperature, soil bulk density, and soil WFPS. Temperature levels $(T)$ of 278,283 , and $288 \mathrm{~K}$ were achieved by storing the soil and carrying out the experiment in a controlled environment room with temperature and relative humidity controls. Variation in $T$ was $\pm 1 \mathrm{~K}$ for each factor level. Low $(1.25 \mathrm{Mg}$ $\mathrm{m}^{-3}$ ) and high $\left(1.40 \mathrm{Mg} \mathrm{m}^{-3}\right)$ bulk densities $\left(\rho_{\mathrm{b}}\right)$ were selected as similar to conditions in seedbeds prepared using conventional tillage and to conditions achieved after several years of cropping without tillage, respectively (L.N. Mielke, personal communication, 1987). Three levels of WFPS were used: $0.35,0.60$, and $0.85 \mathrm{~m}^{3} \mathrm{H}_{2} \mathrm{O} \mathrm{m} \mathrm{m}^{-3}$ soil pores. The $0.60 \mathrm{~m}^{3} \mathrm{~m}^{-3}$ WFPS treatment was chosen on the assumption that the relationship between WFPS and seed imbibition would be similar to that between WFPS and soil microbial activity reported by Linn and Doran (1984) and Doran et al. (1988). The two other values were chosen to provide conditions of low and high water availability to seeds. Calculated total porosity, gravimetric water content, volumetric water content, and water potential for each $\rho_{b} \times$ WFPS treatment level combinations are shown in Table 2 .

Winter wheat (cv. Centurk 78) seeds were used for the experiment. Seed was sieved to ensure that seed of a uniform size was planted. Prior to planting, seed was heat treated $(363 \mathrm{~K}$ for $12 \mathrm{~h}$ in a forced-convection oven) to kill the embryos and prevent germination, so that weight increase due to water absorption could be recorded over time. Seed used in the experiment was stored at $277 \mathrm{~K}$ and $70 \%$ relative humidity. Initial seed water contents are reported in Table 3.

The experiment was conducted as a split-plot design, with the $2 \times 3\left(\rho_{\mathrm{b}} \times\right.$ WFPS $)$ factorial treatments (Steel and Torrie, $1980)$ assigned to the subunits. The main experimental unit was the constant temperature room to which levels of $T$ were assigned over time. The experiment was conducted at the lowest $T$ level $(278 \mathrm{~K}$ ) first, followed by 283 and then $288 \mathrm{~K}$. The experiment was repeated three times for each $T$ level. Individual observation effects were nested with $T$ effects (Steel and Torrie, 1980). Experimental subunits were PVC cylinders (100.0 mm high, 51.7 $\mathrm{mm}$ i.d.). Treatment level combinations and location within the main experimental unit were randomly assigned to each subunit.

Three groups of 10 seeds each (one of heat-killed seeds and two of viable seeds, although the latter were not used in the part of the experiment reported here) were placed between layers of preweighed, premoistened soil (according to the information shown in Table 2, to achieve target WFPS for each treatment level combination). Soil and seed groups were introduced alternately into the cylinders, and then the contents of each cylinder were packed with a hydraulic press to obtain $75.0-\mathrm{mm}$ high soil cores with the desired $\rho_{b}$ and WFPS. Seed spatial dis-
Table 2. Calculated total porosity, gravimetric and volumetric water contents to achieve target water-filled pore space (WFPS) at predetermined bulk densities $\left(\rho_{b}\right)$, and measured soil matric potentials.

\begin{tabular}{lccccc}
\hline & & & \multicolumn{2}{c}{ Water content } & \\
\cline { 4 - 5 }$\rho_{\mathbf{b}}$ & WFPS & $\begin{array}{c}\text { Total } \\
\text { porosity } \dagger\end{array}$ & $\begin{array}{c}\text { Gravi- } \\
\text { metric }\end{array}$ & $\begin{array}{c}\text { Volu- } \\
\text { metric }\end{array}$ & $\begin{array}{c}\text { Matric } \\
\text { potential } \neq\end{array}$ \\
\hline $\mathrm{Mg} \mathrm{m}^{-3}$ & & & $\mathrm{~kg} \mathrm{kg-1}^{-1}$ & $\mathrm{~m}^{3} \mathrm{~m}^{-3}$ & $\mathrm{MPa}$ \\
1.25 & 0.35 & 0.53 & 0.15 & 0.18 & $<-1.500$ \\
& 0.60 & 0.53 & 0.25 & 0.32 & -0.200 \\
& 0.85 & 0.53 & 0.36 & 0.45 & -0.001 \\
1.40 & 0.35 & 0.47 & 0.12 & 0.17 & $<-1.500$ \\
& 0.60 & 0.47 & 0.20 & 0.28 & -0.300 \\
& 0.85 & 0.47 & 0.29 & 0.40 & -0.070 \\
\hline
\end{tabular}

$\dagger$ Assuming a particle density of $2.65 \mathrm{Mg}$ soil solids $\mathrm{m}^{-3}$ soil solids.

$\ddagger$ Obtained with a pressure-plate apparatus (Richards, 1965; Klute, 1986) without replication.

tribution within each seed layer was planned so that interference between seeds was minimized. Seed groups were weighed to the nearest $0.1 \mathrm{mg}$ immediately before each experiment setting.

Final water content of seeds was measured at eight sampling times per replication: 3, 9, 21, 45, 93, 141, 189, and $237 \mathrm{~h}$ after setting. At each sampling time, one core per treatment level combination $\left(\rho_{b} \times\right.$ WFPS) was pushed out of the cylinder, the seeds recovered, gently rinsed with tap water, and immediately blotted with paper towels. Seeds were weighed to the nearest 0.1 $\mathrm{mg}$, oven dried $(363 \mathrm{~K}$ for $48 \mathrm{~h}$ in forced-convection conventional oven), and reweighed. Initial and final seed water contents were calculated.

Based on a pilot experiment (data not shown), we found that the model postulated by Blacklow (1972) to explain water uptake by corn (Zea mays L.) seeds fit our data for wheat seeds:

$$
\theta_{\mathrm{s}(t)}=(m+o t)-\left(m-\theta_{\mathrm{s}(0)}\right) \exp (-q t)
$$

where $\theta_{\mathrm{s}(t)}$ is seed water content $\left(\mathrm{kg} \mathrm{kg}^{-1}\right)$, at time $t(\mathrm{~h})$ elapsed since planting, $\theta_{\mathrm{s}(0)}$ is initial seed water content $\left(\mathrm{kg} \mathrm{kg}^{-1}\right)$, and $m, o$, and $q$ are curve-shaping parameters.

The nonlinear least square method (steepest descent iteration method: Draper and Smith, 1981; SAS Institute, 1985) was used to fit data to the model. The nonlinear regression procedure (PROC NLIN) in the Statistical Analysis System (SAS Institute, 1985) was employed to perform curve-fitting operations for each treatment level combination.

The seed water potential-seed water content relationship was determined by soaking groups of 15 heat-killed seeds in polyethylene glycol 8000 (PEG) solutions of different concentrations until seed weight stabilized, at which time seed water potential was assumed to be equal to solution potential. Water potentials of the solutions were calculated as proposed by Michel (1983). A log-transformed intrinsically linear model (Steel and Torrie, 1980) adequately described $\left(r^{2}=0.99\right)$ the changes in the logarithm of seed water content caused by changes in the logarithm of the solution osmotic suction (Fig. 1). Seed water potential could be estimated by solving the regression model for the logarithm of solution suction and calculating the antilogarithm. The resulting function is:

$$
\psi_{\mathrm{s}}=-\exp \left[\left(\log \theta_{\mathrm{s}}+0.1757\right) /-0.2992\right]
$$

where $\psi_{\mathrm{s}}$ is seed water potential (MPa) and $\theta_{\mathrm{s}}$ is seed water content $\left(\mathrm{kg} \mathrm{kg}^{-1}\right)$.

\section{RESULTS AND DISCUSSION}

We found that seeds exposed to high soil water content for $>93 \mathrm{~h}$ lost dry matter through seed coat cracks produced by swelling pressure. This phenomenon resulted in biased initial and final seed water contents for the longer 
Table 3. Results of fitting Blacklow's (1972) model to initial seed water content $\left(\theta_{s(0)}\right)$ in wheat as affected by time and different combinations of temperature $(T)$, bulk density $\left(\rho_{b}\right)$, and water-filled pore space (WFPS).

\begin{tabular}{|c|c|c|c|c|c|c|c|c|}
\hline \multirow[b]{2}{*}{$T$} & \multirow[b]{2}{*}{$\rho_{\mathrm{b}}$} & \multirow[b]{2}{*}{ WFPS } & \multicolumn{3}{|c|}{ Function parameters, \pm SE } & \multirow[b]{2}{*}{$R^{2}$} & \multirow[b]{2}{*}{ RMSE $\dagger$} & \multirow[b]{2}{*}{$\theta_{\mathrm{s}(0)}(\mathrm{SD})$} \\
\hline & & & $m$ & $o$ & $q$ & & & \\
\hline K & $\mathrm{Mg} \mathrm{m}^{-3}$ & & $\mathrm{~kg} \mathrm{~kg}^{-1}$ & $\mathrm{~kg} \mathrm{~kg}^{-1} \mathrm{~h}^{-1}$ & $h^{-1}$ & & 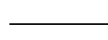 & $-1 \ldots$ \\
\hline \multirow[t]{2}{*}{278} & 1.25 & $\begin{array}{l}0.35 \\
0.60 \\
0.85\end{array}$ & $\begin{array}{l}0.41 \pm 0.03 \\
0.39 \pm 0.03 \\
0.37 \pm 0.02\end{array}$ & $\begin{array}{l}0.0009 \pm 0.0004 \\
0.0024 \pm 0.0004 \\
0.0034 \pm 0.0003\end{array}$ & $\begin{array}{l}0.074 \pm 0.01 \\
0.094 \pm 0.01 \\
0.120 \pm 0.02\end{array}$ & $\begin{array}{l}0.982 \\
0.987 \\
0.991\end{array}$ & $\begin{array}{l}0.017 \\
0.020 \\
0.020\end{array}$ & $\begin{array}{l}0.08(0.01) \\
0.08(0.01) \\
0.08(0.01)\end{array}$ \\
\hline & 1.40 & $\begin{array}{l}0.35 \\
0.60 \\
0.85\end{array}$ & $\begin{array}{l}0.36 \pm 0.03 \\
0.41 \pm 0.03 \\
0.40 \pm 0.03\end{array}$ & $\begin{array}{l}0.0005 \pm 0.0004 \\
0.0019 \pm 0.0003 \\
0.0024 \pm 0.0004\end{array}$ & $\begin{array}{l}0.075 \pm 0.01 \\
0.090 \pm 0.01 \\
0.120 \pm 0.02\end{array}$ & $\begin{array}{l}0.973 \\
0.988 \\
0.983\end{array}$ & $\begin{array}{l}0.017 \\
0.020 \\
0.022\end{array}$ & $\begin{array}{l}0.08(0.01) \\
0.08(0.01) \\
0.08(0.01)\end{array}$ \\
\hline \multirow[t]{2}{*}{283} & 1.25 & $\begin{array}{l}0.35 \\
0.60 \\
0.85\end{array}$ & $\begin{array}{l}0.39 \pm 0.02 \\
0.39 \pm 0.02 \\
0.44 \pm 0.03\end{array}$ & $\begin{array}{l}0.0018 \pm 0.0003 \\
0.0030 \pm 0.0003 \\
0.0031 \pm 0.0004\end{array}$ & $\begin{array}{l}0.115 \pm 0.02 \\
0.150 \pm 0.02 \\
0.137 \pm 0.02\end{array}$ & $\begin{array}{l}0.982 \\
0.986 \\
0.980\end{array}$ & $\begin{array}{l}0.020 \\
0.020 \\
0.028\end{array}$ & $\begin{array}{l}0.09(0.03) \\
0.09(0.03) \\
0.09(0.03)\end{array}$ \\
\hline & 1.40 & $\begin{array}{l}0.35 \\
0.60 \\
0.85\end{array}$ & $\begin{array}{l}0.36 \pm 0.02 \\
0.44 \pm 0.02 \\
0.45 \pm 0.03\end{array}$ & $\begin{array}{l}0.0005 \pm 0.0003 \\
0.0017 \pm 0.0003 \\
0.0025 \pm 0.0004\end{array}$ & $\begin{array}{l}0.103 \pm 0.01 \\
0.109 \pm 0.01 \\
0.122 \pm 0.02\end{array}$ & $\begin{array}{l}0.972 \\
0.992 \\
0.983\end{array}$ & $\begin{array}{l}0.017 \\
0.020 \\
0.024\end{array}$ & $\begin{array}{l}0.09(0.03) \\
0.09(0.03) \\
0.09(0.03)\end{array}$ \\
\hline \multirow[t]{2}{*}{288} & 1.25 & $\begin{array}{l}0.35 \\
0.60 \\
0.85\end{array}$ & $\begin{array}{l}0.42 \pm 0.02 \\
0.45 \pm 0.02 \\
0.51 \pm 0.03\end{array}$ & $\begin{array}{l}0.0016 \pm 0.0003 \\
0.0029 \pm 0.0004 \\
0.0029 \pm 0.0004\end{array}$ & $\begin{array}{l}0.146 \pm 0.02 \\
0.160 \pm 0.03 \\
0.129 \pm 0.02\end{array}$ & $\begin{array}{l}0.970 \\
0.976 \\
0.983\end{array}$ & $\begin{array}{l}0.024 \\
0.028 \\
0.028\end{array}$ & $\begin{array}{l}0.11(0.01) \\
0.12(0.01) \\
0.12(0.01)\end{array}$ \\
\hline & 1.40 & $\begin{array}{l}0.35 \\
0.60 \\
0.85\end{array}$ & $\begin{array}{l}0.37 \pm 0.02 \\
0.47 \pm 0.02 \\
0.44 \pm 0.02\end{array}$ & $\begin{array}{l}0.0007 \pm 0.0002 \\
0.0018 \pm 0.0003 \\
0.0032 \pm 0.0004\end{array}$ & $\begin{array}{l}0.151 \pm \mathbf{0 . 0 2} \\
0.133 \pm \mathbf{0 . 0 2} \\
0.180 \pm \mathbf{0 . 0 3}\end{array}$ & $\begin{array}{l}0.963 \\
0.981 \\
0.971\end{array}$ & $\begin{array}{l}0.017 \\
0.022 \\
0.031\end{array}$ & $\begin{array}{l}0.11(0.01) \\
0.11(0.01) \\
0.11(0.01)\end{array}$ \\
\hline
\end{tabular}

+ Root mean square error.

incubation times. Therefore, data from the 141-, 189-, and 237-h samplings were excluded from these analyses.

Results of the statistical procedure performed to fit the Blacklow model (Eq. [1]) to wheat seed final water content data are shown in Table 3. Observed values and curves generated by the fitted model, as a function of time, are shown in Fig. 2. Average coefficient of multiple determination $\left(R^{2}\right)$ was $0.980 \pm 0.008$ with maximum and minimum values of 0.992 and 0.963 , respectively. The model explained $>96 \%$ of the variability in imbibition as a function of time for all $T-\rho_{\mathrm{b}}$-WFPS levels studied.

Equation [1] comprises two distinct functions. The first is a simple linear function $(m+o t)$ referred to as $f(t)$. Blacklow (1972) stated that $f(t)$ represents the capacity of the seed to absorb water. He attributed the positive slope $(o)$ to embryo growth and reported that heat-killed corn seeds did not show a linear phase of imbibition within the range of time he studied. Results of our experiment (Fig. 2) demonstrate that heat-killed wheat seeds followed the same trend. Similar results have been reported by other authors (Hadas and Russo, 1974; Bruckler, 1983; Leopold, 1983; Bouaziz and Bruckler, 1989) for other species placed in different environments (osmotic solutions, soil, and media with different partial pressures of water vapor). Since embryo growth did not occur in our study, we suggest that $f(t)$ represents the maximum capacity (space within the seed available to be filled with water; $\mathrm{kg} \mathrm{kg}^{-1}$ ) of the seed to absorb water at time $t$ during imbibition. This function shows how the capacity of the seed to absorb water increases as imbibition proceeds. During the early stages of imbibition, the actual amount of water absorbed is far less than the maximum defined by $f(t)$. Increasing seed capacity during the exponential phase of water absorption may be due to the appearance of new active sites for water adsorption as a result of unfolding of biopolymers as water is absorbed (Vertucci, 1989).

The second part of the model (Eq. [1]) is an exponential function $\left[\left(m-\theta_{\mathrm{s}(0)}\right) \exp (-q t)\right]$. This function describes the reduction in the total capacity of the seed available to be filled with water $[f(t)]$ as water enters the seed during the exponential phase. We assumed that when $\theta_{\mathrm{s}(\mathrm{t})}$ becomes asymptotic to $f(t)$, further increases in seed capacity are exclusively due to increases in seed volume resulting from the volume of water that enters the seed (Vertucci, 1989). It is important to point out that during the exponential phase, increases in seed volume are assumed to be greater than the volume of entering water because of changes in configuration of seed constituents (Leopold, 1983; Vertucci, 1989).

Since we have assumed that $f(t)$ is a representation of the seed's maximum capacity to absorb water at any time $t$, parameter $m$ (the $y$-intercept) represents the seed's capacity to absorb water at planting. Therefore, $m$ should be dependent on size-related seed characteristics instead of soil variables considered. Values of parameter $m$ averaged

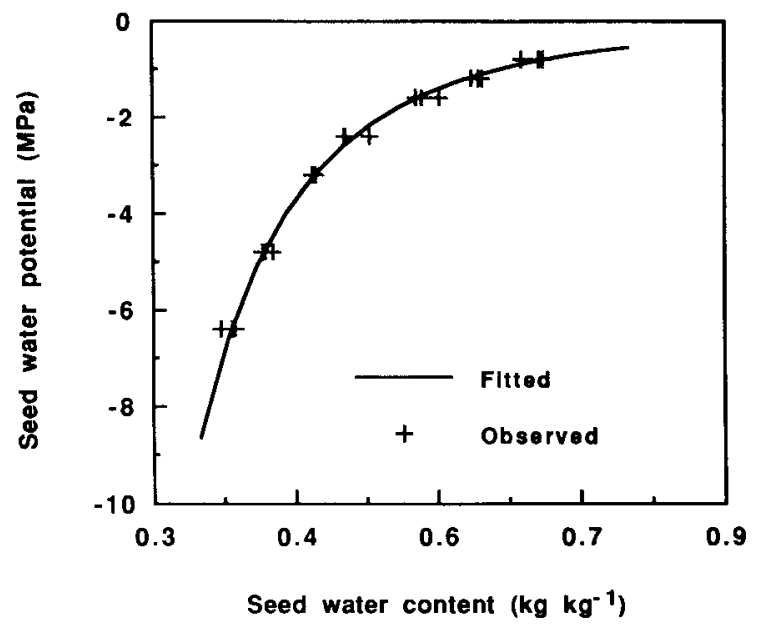

Fig. 1. Observed (points; four replications) and predicted (line) relationships between seed water content and seed water potential. The equation $\psi_{s}=-\exp \left[\left(\log \theta_{\mathrm{s}}+\mathbf{0 . 1 7 5 7}\right) /-0.2992\right]$, where $\psi_{\mathrm{s}}$ is seed water potential (MPa) and $\theta_{\mathrm{s}}$ is seed water content $\left(\mathrm{kg} \mathrm{kg}^{-1}\right)$, for the relationship was suggested by Michel (1983) and fitted to the observed data $\left(r^{2}=0.99\right)$. 

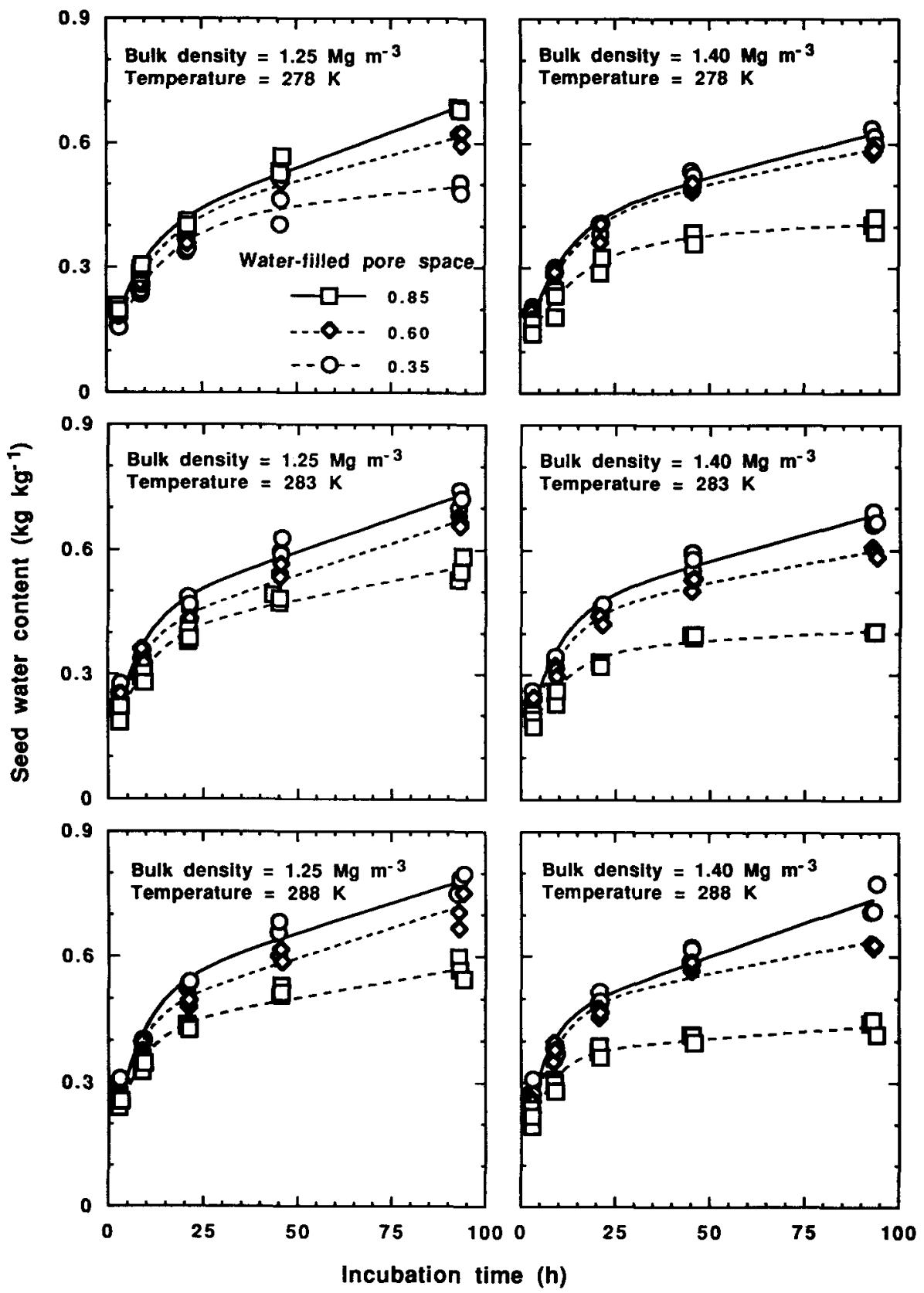

Fig. 2. Observed (points) and predicted (lines) values of wheat seed final water content as a function of time for a Sharpsburg soil and different combinations of temperature, bulk density, and water-filled pore space.

$0.416 \pm 0.041 \mathrm{~kg} \mathrm{~kg}^{-1}$ with minimum and maximum values 0.360 and $0.510 \mathrm{~kg} \mathrm{~kg}^{-1}$, respectively (Table 3 ).

Initial seed weight (when placed into the soil) averaged $23.8 \mathrm{mg}$ with a range of $2.9 \mathrm{mg}$. In general, larger values of initial seed weight generated larger values of $m$. A highly significant $(P<0.01)$ but not strong correlation $(r=0.51)$ was found between initial seed weight and parameter $m$. Although a relationship exists between these variables, it was not adequate to predict $m$.

Parameter $o$ represents the rate of increase in the capacity of the seed to hold water. During the linear phase of imbibition, $o$ is the same as the rate of water uptake by seeds. On the other hand, parameter $q$ represents the rate of uptake during the exponential phase. Although seed water potential and hydraulic conductivity control the rate of water uptake at low seed water contents during the ini- tial phase of imbibition (Shaykewich and Williams, 1971b); a few hours after seeds are placed in the soil, the seed changes drastically (Ward and Shaykewich, 1972) and imbibition becomes more dependent on soil condition. At that time, the soil determines how and when soil water reaches the seed and how it is absorbed by the seed. Consequently, soil conditions determine the magnitude of $o$ and $q$.

Highly significant $(P<0.01)$ multiple linear relationships (Draper and Smith, 1981) were found between both rate-defining parameters $(o$ and $q)$ and $T$, observed values of WFPS, and $\rho_{\mathrm{b}}$. Models obtained to explain variation in parameter $o$ and $q$ were:

$$
\begin{gathered}
o_{\mathrm{e}}=-0.0064+0.0038 \text { WFPS }-0.005 \rho_{\mathrm{b}} \\
\left(R^{2}=0.88\right)
\end{gathered}
$$


Table 4. Seed water content $\left(\theta_{s}\right)$, seed water potential $\left(\psi_{s}\right)$, and rate of water uptake by wheat seeds under different combinations of temperature $(T)$, bulk density $\left(\rho_{h}\right)$, and water-filled pore space (WFPS) at two times of incubation.

\begin{tabular}{|c|c|c|c|c|c|c|c|c|}
\hline \multirow[b]{2}{*}{$T$} & \multirow[b]{2}{*}{$\rho_{b}$} & \multirow[b]{2}{*}{ WFPS } & \multicolumn{2}{|c|}{$\theta_{\mathrm{s}} \dagger$} & \multicolumn{2}{|c|}{$\psi_{\mathrm{s}} \ddagger$} & \multicolumn{2}{|c|}{$\begin{array}{c}\text { Water } \\
\text { uptake rate }\end{array}$} \\
\hline & & & $3 \mathrm{~h}$ & $21 \mathrm{~h}$ & $3 \mathrm{~h}$ & $21 \mathrm{~h}$ & $3 \mathrm{~h}$ & $21 \mathrm{~h}$ \\
\hline $\mathbf{K}$ & \multicolumn{2}{|l|}{$\mathrm{Mg} \mathrm{m}^{-3}$} & \multicolumn{2}{|c|}{$-\mathrm{kg} \mathrm{kg}^{-1}$} & \multicolumn{2}{|c|}{$-\mathrm{MPa}-$} & \multicolumn{2}{|c|}{$\mathrm{g} \mathrm{kg}^{-1} \mathrm{~h}^{-1}$} \\
\hline 278 & 1.25 & $\begin{array}{l}0.35 \\
0.60 \\
0.85\end{array}$ & $\begin{array}{l}0.15 \\
0.16 \\
0.18\end{array}$ & $\begin{array}{l}0.35 \\
0.40 \\
0.42\end{array}$ & $\begin{array}{r}-146.7 \\
-118.2 \\
-79.8\end{array}$ & $\begin{array}{l}-8.6 \\
-5.6 \\
-4.7\end{array}$ & $\begin{array}{l}21.0 \\
24.0 \\
28.0\end{array}$ & $\begin{array}{l}6.1 \\
6.5 \\
6.2\end{array}$ \\
\hline & 1.40 & $\begin{array}{l}0.35 \\
0.60 \\
0.85\end{array}$ & $\begin{array}{l}0.13 \\
0.16 \\
0.17\end{array}$ & $\begin{array}{l}0.31 \\
0.40 \\
0.41\end{array}$ & $\begin{array}{r}-236.7 \\
-118.2 \\
-96.6\end{array}$ & $\begin{array}{r}-13.0 \\
-5.6 \\
-5.1\end{array}$ & $\begin{array}{l}17.0 \\
24.0 \\
26.0\end{array}$ & $\begin{array}{l}4.9 \\
6.4 \\
6.2\end{array}$ \\
\hline 283 & 1.25 & $\begin{array}{l}0.35 \\
0.60 \\
0.85\end{array}$ & $\begin{array}{l}0.18 \\
0.21 \\
0.22\end{array}$ & $\begin{array}{l}0.40 \\
0.44 \\
0.48\end{array}$ & $\begin{array}{l}-79.8 \\
-47.7 \\
-40.8\end{array}$ & $\begin{array}{l}-5.6 \\
-4.0 \\
-3.0\end{array}$ & $\begin{array}{l}26.0 \\
32.0 \\
35.0\end{array}$ & $\begin{array}{l}4.9 \\
5.0 \\
5.8\end{array}$ \\
\hline & 1.40 & $\begin{array}{l}0.35 \\
0.60 \\
0.85\end{array}$ & $\begin{array}{l}0.16 \\
0.19 \\
0.21\end{array}$ & $\begin{array}{l}0.34 \\
0.44 \\
0.47\end{array}$ & $\begin{array}{r}-118.2 \\
-66.6 \\
-47.7\end{array}$ & $\begin{array}{l}-9.5 \\
-4.0 \\
-3.2\end{array}$ & $\begin{array}{l}21.0 \\
29.0 \\
33.0\end{array}$ & $\begin{array}{l}3.8 \\
5.6 \\
5.9\end{array}$ \\
\hline 288 & 1.25 & $\begin{array}{l}0.35 \\
0.60 \\
0.85\end{array}$ & $\begin{array}{l}0.23 \\
0.25 \\
0.25\end{array}$ & $\begin{array}{l}0.44 \\
0.50 \\
0.55\end{array}$ & $\begin{array}{l}-35.1 \\
-26.6 \\
-26.6\end{array}$ & $\begin{array}{l}-4.0 \\
-2.6 \\
-1.9\end{array}$ & $\begin{array}{l}31.0 \\
36.0 \\
38.0\end{array}$ & $\begin{array}{l}3.7 \\
4.7 \\
6.3\end{array}$ \\
\hline & 1.40 & $\begin{array}{l}0.35 \\
0.60 \\
0.85\end{array}$ & $\begin{array}{l}0.21 \\
0.23 \\
0.26\end{array}$ & $\begin{array}{l}0.37 \\
0.48 \\
0.50\end{array}$ & $\begin{array}{l}-47.7 \\
-35.1 \\
-23.3\end{array}$ & $\begin{array}{l}-7.2 \\
-3.0 \\
-2.6\end{array}$ & $\begin{array}{l}26.0 \\
34.0 \\
38.0\end{array}$ & $\begin{array}{l}2.4 \\
4.7 \\
4.8\end{array}$ \\
\hline
\end{tabular}

† Calculated with Eq. [1]

$\ddagger$ Calculated with Eq. [2].

$\$$ Calculated by differentiating Eq. [1].

$$
\begin{gathered}
q_{\mathrm{e}}=-1.556+0.0058 T+0.0425 \text { WFPS } \\
\left(R^{2}=0.78\right)
\end{gathered}
$$

where $o_{\mathrm{e}}$ is the estimated parameter $o, q_{\mathrm{e}}$ is the estimated parameter $q$, WFPS is in $\mathrm{m}^{3} \mathrm{~m}^{-3}, \rho_{\mathrm{b}}$ is in $\mathrm{Mg} \mathrm{m}^{-3}$, and $T$ is in $\mathrm{K}$. Temperature and $\rho_{\mathrm{b}}$ were eliminated as independent variables from Eq. [3] and [4], respectively, because their effects were not significant $(P>0.05)$. Quadratic effects of $T$ and WFPS were not significant.

Parameter $q$ was greater at greater $T$ (Table 3 ); consequently, the rate of water uptake by seeds was also greater (Table 4). The viscosity of water depends on $T$ and influences seed imbibition rate because of its effect on soil and seed hydraulic conductivities (Murphy and Noland, 1982; Vertucci and Leopold, 1983). Assuming that the pore geometry of soil cores treated alike (at different temperatures) is similar, intrinsic permeability may be assumed to be equal as well (Hillel, 1980b). Therefore, a correction factor for unsaturated hydraulic conductivity at the different temperatures was calculated from values of water density and viscosity corresponding to each level of $T$. We estimated that the $283 \mathrm{~K}$ and $278 \mathrm{~K}$ levels of $T$ presented 13 and $25 \%$ less conductivity, respectively, than the $288 \mathrm{~K}$ level, because of changes in water viscosity and density.

In a natural system, increased WFPS means greater soil water content, soil matric potential (less negative), and hydraulic conductivity (Hillel, 1980b). On the other hand, under natural conditions, increased $\rho_{b}$ produces an increase in seed-soil contact (Hillel, 1972) and, within certain limits, may also improve unsaturated hydraulic conductivity due to better pore continuity. Partial regression coefficients for WFPS in Eq. [3] and [4] and data in Table 4 agree with the theoretical effect of WFPS on water uptake rate. However, the negative partial regression coefficients for $\rho_{b}$ in Eq. [3] and reductions in water uptake rate with increased $\rho_{b}$ in Table 4 may indicate physical constraints on seed swelling as a result of greater $\rho_{b}$ around the seed
Table 5. Time to completion of the exponential phase of Blacklow's (1972) model $\left(t_{i}\right)$ and seed water content at that moment $\left(\theta_{s(i)}\right)$ for different combinations of incubation temperature (three values of $T$, expressed in $K$ ), bulk density $\left(\rho_{b}\right)$, and water-filled pore

\begin{tabular}{|c|c|c|c|c|c|c|c|}
\hline \multirow[b]{2}{*}{$\rho_{b}$} & \multirow[b]{2}{*}{ WFPS } & \multicolumn{3}{|c|}{$t_{i}$} & \multicolumn{3}{|c|}{$\theta_{\mathrm{s}(i)}$} \\
\hline & & $278 \mathrm{~K}$ & $283 \mathrm{~K}$ & $288 \mathrm{~K}$ & $278 \mathrm{~K}$ & $283 \mathrm{~K}$ & $288 \mathrm{~K}$ \\
\hline \multicolumn{2}{|c|}{$\mathrm{Mg} \mathrm{m}^{-3}$} & \multicolumn{3}{|c|}{$\longrightarrow \mathbf{h} \longrightarrow$} & \multicolumn{3}{|c|}{$-\mathbf{k g ~ k g}^{-1}$} \\
\hline 1.25 & $\begin{array}{l}0.35 \\
0.60 \\
0.85\end{array}$ & $\begin{array}{l}47.3 \\
36.6 \\
28.1\end{array}$ & $\begin{array}{l}29.6 \\
22.7 \\
26.0\end{array}$ & $\begin{array}{l}23.6 \\
21.9 \\
28.4\end{array}$ & $\begin{array}{l}0.44 \\
0.47 \\
0.46\end{array}$ & $\begin{array}{l}0.43 \\
0.45 \\
0.51\end{array}$ & $\begin{array}{l}0.45 \\
0.50 \\
0.58\end{array}$ \\
\hline 1.40 & $\begin{array}{l}0.35 \\
0.60 \\
0.85\end{array}$ & $\begin{array}{l}44.5 \\
38.9 \\
28.9\end{array}$ & $\begin{array}{l}32.1 \\
32.7 \\
29.4\end{array}$ & $\begin{array}{l}21.6 \\
27.0 \\
19.4\end{array}$ & $\begin{array}{l}0.37 \\
0.47 \\
0.46\end{array}$ & $\begin{array}{l}0.37 \\
0.49 \\
0.51\end{array}$ & $\begin{array}{l}0.38 \\
0.51 \\
0.49\end{array}$ \\
\hline
\end{tabular}
space (WFPS).

(Hadas, 1977). Increased $\rho_{b}$ may limit the possibility of increasing the capacity of the seed to absorb water $[f(t)]$ by lowering its rate of increase (parameter $o$; Table 3). Likewise, unnatural pore geometry caused by the way the soil was handled in this experiment may have contributed to reduced hydraulic conductivity with increasing $\rho_{b}$.

Blacklow (1972) hypothesized using the completion time for the exponential phase of imbibition as a measure of the influence of surrounding conditions. It could be argued, he said, that germination occurs when the exponential phase approaches the linear phase and that time to this event could be used as an analytical solution for time of germination.

To pursue this idea, we transformed Eq. [1] to:

$$
t_{i}=\left[\ln \left(m-\theta_{\mathrm{s}(0)}\right)+\ln \left(f(t)-\theta_{\mathrm{s}(\mathrm{t})}\right)\right] / q
$$

where $t_{i}$ is time (h) to the occurrence of event $i$. The expression $f(t)-\theta_{\mathrm{s}(t)}$ represents the fraction of the total seed capacity for absorbing water that is available to be filled with water. If we assume that the exponential phase is almost complete when $f(t)-\theta_{\mathrm{s}(\mathrm{t})}=0.01 \mathrm{~kg} \mathrm{~kg}^{-1}$ (Blacklow, 1972), then time to completion of the exponential phase (event $i$ ) can be estimated. Table 5 shows the values for $t_{i}$ (calculated with Eq. [5] and the above assumption) and $\theta_{\mathrm{s}(\mathrm{i})}$ (calculated with Eq. [1] for the corresponding $t_{i}$ values). In general terms, time to completion of the exponential phase decreases with increasing $T$ and WFPS, but increases with increasing $\rho_{b}$.

Collis-George and Melville $(1975,1978)$ reported that wheat seeds water content at $50 \%$ germination was 0.68 $\mathrm{kg} \mathrm{kg}^{-1}$ when soaked in water; however, when water supply was exclusively in the vapor phase, seed water content for germination was 0.50 (in a saturated atmosphere) or $0.48 \mathrm{~kg} \mathrm{~kg}^{-1}$ (when vapor had to pass through a layer of sand). In our experiment, seed water content at the completion of the exponential phase $\left(\theta_{\mathrm{s}(\mathrm{i})}\right)$ ranged from 0.37 to $0.58 \mathrm{~kg} \mathrm{~kg}^{-1}$ (Table 5). Most values were $\geq 0.43 \mathrm{~kg}$ $\mathrm{kg}^{-1}$, with an average of $0.48 \pm 0.04 \mathrm{~kg} \mathrm{~kg}^{-1}$, which is similar to that cited by Collis-George and Melville (1975, 1978), even though they worked with higher temperature $(293 \pm 1.5 \mathrm{~K})$. Combination of high $\rho_{\mathrm{b}}$, low WFPS, and any of the $T$ levels considered produced $\theta_{\text {s(i) }}$ values $<0.40$ $\mathrm{kg} \mathrm{kg}^{-1}$. This water content seems insufficient to trigger germination; however, the only combination under which no germination was detected was high $\rho_{\mathrm{b}}$, low WFPS, and low $T$ (data not shown).

It is important to indicate that during the process of imbibition, soil WFPS, $\rho_{\mathrm{b}}$, and $T$ can and do change. Sim- 
ilarly, all the processes related to seed imbibition are transient mechanisms whose characteristics depend, to a large extent, on how they occur. These dynamic processes may be described by mathematically complicated, continuous functions requiring input information that is not readily available or is difficult to predict. Depiction and prediction of the process of seed imbibition can be satisfactorily accomplished with such models, but their complexity impedes their use under field conditions.

The data shown here indicate that a close relationship exists between seed imbibition and the combined effects of soil WFPS, $\rho_{b}$, and T. We have shown that wheat seed imbibition may be described by a relatively simple mathematical model, such as that reported by Blacklow (1972). We have also shown that, for soil conditions represented in this experiment, variation in two of the parameters in this model may be explained by the variation in the soil factors considered as variables (WFPS, $\rho_{\mathrm{b}}$, and $T$ ) through other simple mathematical models (Eq. [3] and [4]). All these models (Blacklow, 1972; Eq. [3]; and Eq. [4]) may be used as an algorithm to predict time of occurrence of key seed hydration states for soil conditions similar to those used in this experiment.

\section{REFERENCES}

Bewley, J.D., and M. Black. 1978. Physiology and biochemistry of seeds in relation to germination. Vol. 1. Development, germination and growth. Springer-Verlag, Berlin, East Germany.

Blacklow, W.M. 1972. Mathematical description of the influence of temperature and seed quality on the imbibition by seeds of corn (Zea mays L.). Crop Sci. 12:643-646.

Bruckler, L. 1983. Rôle des propiétés physiques du lit de semences sur l'imbibition et la germination: I. Elaboration d'un modèle du système "terre-graine." Agronomie (Paris) 3:213-222.

Bouaziz, A., and L. Bruckler. 1989. Modeling of wheat imbibition and germination as influenced by soil physical properties. Soil Sci. Soc. Am. J. 53:219-227.

Collis-George, N., and M.D. Melville. 1975. Water absorption by swelling seeds: I. Constant surface boundary condition. Aust. J. Soil Res. 13:141-158.

Collis-George, N. , and M.D. Melville. 1978. Water absorption by swelling seeds: II. Surface condensation boundary condition. Aust. J. Soil Res. 16:291-310.

Crowe, J.H., L.M. Crowe, F.A. Hoekstra, and C.A. Wistrom. 1989. Effects of water and the stability of phospholipid bilayers: The problem of imbibition damage in dry organisms. p. 1-14. In P.C. Stanwood and M.B. McDonald (ed.) Seed moisture. CSSA Spec. Publ. 14. CSSA, Madison, WI.

Doran, J.W., L.N. Mielke, and S. Stamatiadis. 1988. Microbial activity and $\mathrm{N}$ cycling as regulated by soil water-filled pore space. Proc. Conf. Int. Soil Tillage Res. Org., 11th, Edinburgh, Scotland. 11-15 July 1988. Vol. 1.

Draper, N.R., and H. Smith. 1981. Applied regression analysis. 2nd ed. John Wiley \& Sons, New York.

Griffith, D.R., J.V. Mannering, and J.E. Box. 1986. Soil and moisture management with reduced tillage. p. 19-57. $\ln$ M.A. Sprague and G.B. Triplett (ed.) No-tillage and surface-tillage agriculture: The tillage revolution. John Wiley \& Sons, New York.

Hadas, A. 1976. Water uptake and germination of leguminous seeds under changing external water potentials in osmotic solutions. J. Exp. Bot. 27:480-489.

Hadas, A. 1977. Water uptake and germination of leguminous seeds in soil of changing matric and osmotic water potential. J. Exp. Bot. 28:977-985.
Hadas, A., and D. Russo. 1974. Water uptake by seeds as affected by water stress, capillary conductivity and seed-soil water contact: $I$. Experimental study. Agron. J. 66:643-647.

Hegarty, T.W. 1978. The physiology of seed hydration and dehydration and the relation between water stress and the control of germination: A review. Plant Cell Environ. 1:101-119.

Hillel, D. 1972. Soil moisture and seed germination. p. 65-80. In T.T. Kozlowsky (ed.) Water deficits and plant growth. Vol. 3. Academic Press, New York.

Hillel, D. 1980a. Applications of soil physics. Academic Press, New York.

Hillel, D. 1980b. Fundamentals of soil physics. Academic Press, New York.

Hunter, J.R., and A.E. Erickson. 1952. Relation of seed germination to soil moisture tension. Agron. J. 44:107-109.

Klute, A. 1986. Water retention: Laboratory methods. p. 635-662. In A. Klute (ed.) Methods of soil analysis. Part 1. Physical and mineralogical methods. 2nd ed. Agron. Monogr. 9. ASA and SSSA, Madison, WI.

Leopold, A.C. 1980. Temperature effects on soybean imbibition and leakage. Plant Physiol. 65:1096-1098.

Leopold, A.C. 1983. Volumetric components of seed imbibition. Plant Physiol. 73:677-680.

Linn, D.M., and J.W. Doran. 1984. Effect of water-filled pore space on carbon dioxide and nitrous oxide production in tilled and nontilled soils. Soil Sci. Soc. Am. J. 48:1267-1272.

Mayer, A.M., and A. Poljakoff-Mayber. 1982. The germination of seeds. 3rd ed. Pergamon Press, Oxford.

Michel, B.E. 1983. Evaluation of the water potentials of solutions of polyethylene glycol 8000 both in the absence and presence of other solutes. Plant Physiol. 72:66-70.

Mielke, L.N., J.W. Doran, and K.A. Richards. 1986. Physical environment near the surface of plowed and no-tilled soils. Soil Till. Res. $7: 355-366$

Murphy, J.B., and T.L. Noland. 1982. Temperature effects on seed imbibition and leakage mediated by viscosity and membranes. Plant Physiol. 69:428-431.

Richards, L.A. 1965. Physical condition of water in soil. p. 128-152. In C.A. Black (ed.) Methods of soil analysis. Part 1. Physical and mineralogical properties, including statistics of measurement and sampling. 1st ed. Agron. Monogr. 9. ASA, Madison, WI.

SAS Institute. 1985. SAS user's guide: Statistics. Version 5. 2nd ed. SAS Inst., Cary, NC.

Shaykewich, C.F., and J. Williams. 1971a. Influence of hydraulic properties of soil on pre-germination water absorption by rapeseed. Agron. J. 63:454-457.

Shaykewich, C.F., and J. Williams. 1971b. Resistance to water absorption in germinating rapeseed (Brassica napus L.). J. Exp. Bot. 22:19-24

Simon, E.W. 1984. Early events in germination. p. 77-115. In D.R. Murray (ed.) Seed physiology. Vol. 2. Germination and reserve mobilization. Academic Press, Orlando, FL.

Singh, K.P., and K. Singh. 1982. Stress physiological studies on seed germination and seedling growth of some wheat hybrids. Indian J. Plant Physiol. 25:180-186.

Steel, R.G.D., and J.H. Torrie. 1980. Principles and procedures of statistics: A biometrical approach. 2nd ed. McGraw-Hill Book Co., New York.

Unger, P.W., and T.M. McCalla. 1980. Conservation tillage systems. Adv. Agron. 33:1-58.

Vertucci, C.W. 1989. The kinetics of seed imbibition: Controlling factors and relevance to seedling vigor. p. 93-115. In P.C. Stanwood and M.B. McDonald (ed.) Seed moisture. CSSA Spec. Publ. 14. CSSA, Madison, WI.

Vertucci, C.W., and A.C. Leopold. 1983. Dynamics of imbibition by soybean embryos. Plant Physiol. 72:190-193.

Ward, J., and C.F. Shaykewich. 1972. Water absorption by wheat seeds as influenced by hydraulic properties of soil. Can. J. Soil Sci. $52: 99-105$

Williams, J., and C.F. Shaykewich. 1971. The influence of soil water matric potential and hydraulic conductivity on the germination of rape (Brassica napus L.). J. Exp. Bot. 22:586-597. 